\title{
Potassium Fertilization Affects Soil K, Leaf K Concentration, and Nut Yield and Quality of Mature Pistachio Trees
}

\author{
Qiupeng Zeng and Patrick H. Brown \\ Department of Pomology, University of California, Davis, CA 95616
}

Brent A. Holtz

Pomology Farm Adviser, Madera Co., CA 93637

Additional index words. critical leaf $\mathrm{K}$ value, calcium, magnesium

\begin{abstract}
A field experiment was conducted from 1996 to 1998 to examine the effects of K fertilization on leaf $\mathrm{K}$, nut yield, and quality in pistachio (Pistacia vera $\mathrm{L}$.). There were six treatments, including four annual rates of $\mathrm{K}$ application $\left(0,110,220\right.$, and $\left.330 \mathrm{~kg}^{-h^{-1}}\right)$ and three $\mathrm{K}$ sources $\left(\mathrm{K}_{2} \mathrm{SO}_{4}, \mathrm{KCl}\right.$, and $\left.\mathrm{KNO}_{3}\right)$. Pistachio trees exhibited highly fluctuating seasonal leaf $K$ levels. Leaf $K$ concentration was low $\left(<10 \mathrm{~g} \cdot \mathrm{kg}^{-1}\right)$ during spring flush, increased dramatically during fruit development, and declined rapidly after harvest. Leaf $K$ concentration increased following $K$ fertilization. Potassium fertilization at the rate of 110 to $220 \mathrm{~kg} \cdot \mathrm{ha}^{-1} \mathrm{~K}$ significantly increased nut yield and quality, but nut yield tended to decrease when the annual rate exceeded $220 \mathrm{~kg} \cdot \mathrm{ha}^{-1} \mathrm{~K}$. There were no significant differences among the $K$ sources in their effects on leaf $K$ concentration, nut yield, and quality. The use of $\mathrm{KCl}$ as a $\mathrm{K}$ source for 3 years did not increase leaf $\mathrm{Cl}$ concentration. There was a significant, positive correlation between nut yield and leaf $K$ concentration during nut fill. The critical leaf $K$ value for optimal pistachio production determined from 3 years' cumulative data was $16.9 \mathrm{~g} \cdot \mathbf{k g}^{-1}$. For sustained production in highly productive pistachio orchards, we recommend annual application rates of 110 to $220 \mathrm{~kg} \cdot \mathrm{ha}^{-1} \mathrm{~K}$, using $\mathrm{K}_{2} \mathrm{SO}_{4}, \mathrm{KCl}$, or $\mathrm{KNO}_{3}$.
\end{abstract}

Although fertilizers have played an important role in California pistachio production, $\mathrm{K}$ fertilization has been largely ignored. Consequently, $\mathrm{K}$ deficiency has affected the productivity of pistachio treesin many orchards (Brown, 1995). The causes for K deficiency are primarily: 1) limited use of $\mathrm{K}$ fertilizers; 2) increased yield, which removes more $\mathrm{K}$ from the soil (Zeng et al., 1999); 3) strong soil K fixation (Olk et al., 1995), reducing soil K availability (Cassman et al., 1989); and 4) excessive use of $\mathrm{N}$ fertilizers (Weinbaum et al., 1992), particularly ammonium-N that tends to acidify the soil and inhibit Kuptake(Chung and Zasoski, 1993). If $\mathrm{K}$ fertilizers are not adequately applied to replenish the soil $\mathrm{K}$ pools, $\mathrm{K}$ deficiency will increase in severity and extent in pistachio.

Pistachio is characterized by alternate bearing, with yield varying widely between on- and off-years (Johnson and Weinbaum, 1987). Alternate bearing strongly influences $\mathrm{K}$ uptake and distribution in pistachio trees (Picchioni et al., 1997; Rosecrance et al., 1996, 1998; Weinbaum et al., 1994). Nonetheless, current fertilization practices in the California

Received for publication 12 Oct. 1999. Accepted for publication 25 Apr. 2000. We appreciate the research grants from the California Pistachio Commission and the Potash and Phosphate Institute. The cost of publishing this paper was defrayed in part by the payment of page charges. Under postal regulations, this paper therefore must be hereby marked advertisement solely to indicate this fact. for pistachio trees is 7 to $10 \mathrm{~g} \cdot \mathrm{kg}^{-1}$; this was developed based on the expression of visual $\mathrm{K}$ deficiency symptoms on the leaf (Ashworth et al., 1985; Brown, 1995). In California, however, leaf $\mathrm{K}$ concentrations of $<10 \mathrm{~g} \cdot \mathrm{kg}^{-1} \mathrm{~K}^{+}$at nut fill are uncommon, even in orchards not fertilized with K (Picchioni et al., 1997; Uriu and Crane, 1977; Zeng et al., 1997, 1998). Furthermore, $\mathrm{K}$ deficiency is often identified in heavily-cropping pistachio trees with a leaf $\mathrm{K}$ concentration $>15 \mathrm{~g} \cdot \mathrm{kg}^{-1} \mathrm{~K}^{+}$. Currently recommended critical leaf $\mathrm{K}$ values may be too low to reflect $\mathrm{K}$ fertilization requirement. Potassium diagnostic criteria should be developed in association with optimal yield levels (Righetti et al., 1990).

Limited use of $\mathrm{K}$ in pistachio is associated with a limited knowledge of $\mathrm{K}$ nutrition and lack of documented effects of $\mathrm{K}$ on improving nut yield and quality. The objectives of this study were to: 1) determine the effects of $\mathrm{K}$ fertilization on pistachio leaf $\mathrm{K}$, nut yield and quality; 2) develop K fertilization recommendations; and 3) refine the K diagnostic criteria for optimal production based on nut yield responses to $\mathrm{K}$.

\section{Materials and Methods}

Orchard and soil descriptions. A field experiment was conducted from 1996 to 1998 on mature 'Kerman' pistachio trees in Agri World, a commercial pistachio orchard located in Madera Co., Calif. The soil is a San Joaquin sandy loam (loamy, kaolinitic, thermic, Typic Durixeralfs) derived from old granitic alluvium; it contains large amounts of kaolinite, followed by vermiculite and montmorillonite. The 15-year-old trees were planted on $P$. atlantica Desf. rootstocks, at a spacing of $5 \times$ $6 \mathrm{~m}$ (316 trees/ha). The orchard had not previously been treated with $\mathrm{K}$ fertilizers and was irrigated using microsprinklers for $8 \mathrm{~h}$ at a water pressure of $\approx 1 \mathrm{~kg} \cdot \mathrm{cm}^{-2}$ every $4 \mathrm{~d}$.

Before the experiment commenced, soil samples were collected from nonfertilized areas at $0-30 \mathrm{~cm}$ depth, air-dried at room temperature, crushed to pass a 2-mm sieve, and mixed thoroughly for analysis. The soil had a $\mathrm{pH}$ of 7.3 as measured in a 1 soil : 1 water suspension, and a sandy loam texture, with $7 \%$ clay, $25 \%$ silt, and $68 \%$ sand, as determined using the pipet method (Gee and Bauder, 1986). Initial soil $\mathrm{NH}_{4}{ }^{+}$-extractable $\mathrm{K}^{+}$was 2.1 $\mathrm{mmol} \cdot \mathrm{kg}^{-1}$. The soil had a CEC of $85 \mathrm{mmol}$ $(+) \cdot \mathrm{kg}^{-1}$, as determined using the ammonium acetate method (Hendershot et al., 1993), and
Optimal K nutrition is essential for optimal production. Currently, the critical leaf K value
Table 1. K sources and annual application rates used for the pistachio field experiment.

\begin{tabular}{|c|c|c|c|c|}
\hline \multicolumn{2}{|r|}{ Treatments } & \multicolumn{3}{|c|}{ Fertilizers used $\left(\mathrm{kg} \cdot \mathrm{ha}^{-1}\right)$} \\
\hline K source & Application rate $\left(\mathrm{kg} \cdot \mathrm{ha}^{-1} \mathrm{~K}\right)$ & $\mathrm{K}_{2} \mathrm{SO}_{4}$ & $\mathrm{KCl}$ & $\mathrm{KNO}_{3}$ \\
\hline Control & 0 & --- & --- & +-- \\
\hline \multirow[t]{3}{*}{$\mathrm{K}_{2} \mathrm{SO}_{4}$} & 110 & 262 & --- & --- \\
\hline & 220 & 524 & --- & --- \\
\hline & 330 & 786 & --- & --- \\
\hline $\mathrm{KCl}$ & 220 & --- & 440 & --- \\
\hline $\mathrm{KNO}_{3}$ & 220 & --- & --- & 611 \\
\hline
\end{tabular}

${ }^{2}$ Quantity of each $\mathrm{K}$ fertilizer used was calculated from its $\mathrm{K}$ analysis, i.e., $\mathrm{K}_{2} \mathrm{SO}_{4}=$ $42 \% \mathrm{~K} ; \mathrm{KCl}=50 \% \mathrm{~K} ; \mathrm{KNO}_{3}=36 \% \mathrm{~K}$. 
an organic matter content of $5.0 \mathrm{~g} \cdot \mathrm{kg}^{-1}$, as determined using the Walkley-Black method (Nelson and Sommers, 1982).

Treatments. There were six treatments (Table 1), including four $\mathrm{K}$ application rates $\left(0,110,220\right.$, and $330 \mathrm{~kg} \cdot \mathrm{ha}^{-1}$ annually) and three $\mathrm{K}$ sources $\left(\mathrm{K}_{2} \mathrm{SO}_{4}, \mathrm{KCl}\right.$, and $\left.\mathrm{KNO}_{3}\right)$. Equal doses of $\mathrm{N}$ were applied as $\left(\mathrm{NH}_{4}\right)_{2} \mathrm{SO}_{4}$ or $\mathrm{NH}_{4} \mathrm{NO}_{3}$ to all treatments to provide balanced salt applications. The treatments were applied to plots consisting of five adjacent trees on the same row, and the plots were arranged in a randomized complete-block design with five blocks. To prevent inter-plot nutrient uptake by penetrating roots, border trees and rows were left between plots.

Fertilizer applications. Potassium was applied annually in four equal splits at 1month intervals from May to August, the period for maximal $\mathrm{K}$ demand and uptake in pistachio (Rosecrance et al., 1996, 1998). The fertilizers used were soluble grade $\mathrm{K}_{2} \mathrm{SO}_{4}$, $\mathrm{KCl}$, and $\mathrm{KNO}_{3}$ supplied by IMC Kalium (Bannockburn, Ill.). After being dissolved in irrigation water, they were applied via a specially designed microsprinkler system that allowed direct injection into individual plots, using the Ag Solution Master fertilizer injection system provided by the Soil Solutions Corporation (Visalia, Calif.). Water pressure was controlled at $1 \mathrm{~kg} \cdot \mathrm{cm}^{2}$ during injection with a microsprinkler emission radius of $\approx 1.3 \mathrm{~m}$.

Soil sampling and Kanalysis. Soil samples were collected after harvest in each year using a soil auger at $15-\mathrm{cm}$ increments from $0-75 \mathrm{~cm}$ depth in the fertigated zones of each experimental tree. Soil subsamples taken from each depth on the same plot were pooled. Five replicate samples were collected, each representing one block. The soil samples were air-dried at room temperature, crushed to pass a 2-mm sieve, and mixed thoroughly for the determination of $\mathrm{NH}_{4}{ }^{+}$-extractable $\mathrm{K}^{+}$. Samples ( $2 \mathrm{~g}$ each) of air-dried soil were weighed and placed into a $50-\mathrm{mL}$ plastic centrifuge tube.

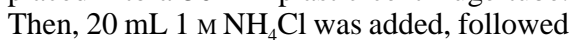
by reciprocal shaking at $200 \mathrm{rpm}$ for $1 \mathrm{~h}$ and centrifugation at $9000 g_{\mathrm{n}}$ for $10 \mathrm{~min}$. The soil suspension was filtered and the extract was analyzed for $\mathrm{K}$ using an atomic absorption spectrophotometer (model 2280; Perkin Elmer, San Jose, Calif.).

Leaf sampling and nutrient analyses. Twenty representative leaves were randomly sampled from nonfruiting branches around each tree in all treatments in July each year. All samples from the same plot were pooled. To examine the seasonal fluctuation of leaf $\mathrm{K}$ in relation to $\mathrm{K}$ applications, 20 representative leaves were sampled monthly from Apr. to Nov. 1998 , dried at $65^{\circ} \mathrm{C}$ for $48 \mathrm{~h}$ in a forcedair oven, and ground to pass a 30-mesh screen for nutrient analyses. About $150 \mathrm{mg}$ of tissue was weighed, placed in a crucible, and dryashed overnight at $500^{\circ} \mathrm{C}$ in a muffle furnace (model 126; Fischer Scientific, Pittsburgh). The ashed samples were dissolved in $10 \mathrm{~mL}$ $1 \mathrm{~N} \mathrm{HNO}_{3}$ and diluted to $50 \mathrm{~mL}$ with deionized water after filtration. The sample extracts were analyzed for $\mathrm{K}^{+}, \mathrm{Ca}^{2+}, \mathrm{Mg}^{2+}$ using an atomic absorption spectrophotometer and for $\mathrm{Cl}^{-}$using a digital chloridometer (model no. 4425000; Kaakebuchler Instruments, Saddle Brook, N.J.)

Fruit harvesting and processing. The pistachio trees were harvested mechanically in September each year. Total fresh weight of fruits (including hulls, shells, and kernels) was recorded by plot. A subsample $(\approx 3 \mathrm{~kg})$ of fresh fruits was collected from each plot and processed using a procedure similar to that described by Picchioni et al. (1997). Each subsample was hulled with a mechanical huller within $12 \mathrm{~h}$ of harvest. After being dried at $65{ }^{\circ} \mathrm{C}$ for $7 \mathrm{~d}$, the hulled nuts were divided into in-shell marketable nuts (filled split nuts) and nonmarketable nuts (nuts with aborted embryos or stained pericarps), and were reweighed to calculate the dry weight : fresh weight ratio of marketable nuts. Total marketable nut yield was determined based on the total fresh weight per plot (obtained at harvest), and the dry weight to fresh weight ratio of marketable nuts in the fruit subsamples, and was expressed as marketable, in-shell nuts $\left(\mathrm{kg} \cdot \mathrm{ha}^{-1}\right)$

The percentages of split nuts, blank nuts, and stained nuts, and the 100-nut weight are the major nut quality criteria used to grade pistachio nuts in California (Ferguson et al., 1995). These parameters were determined by counting and weighing 500 hulled, in-shell nuts randomly collected from each of the dried subsamples in 1998.

Development of $K$ diagnostic criteria. Marketable, in-shell nut yield and leaf K concentration were averaged over 3 years and regression analysis at $P \leq 0.05$ was performed. A second-order regression equation was obtained from each set of data. Maximum nut yield $\left(Y_{100 \%}\right)$ and its corresponding leaf $\mathrm{K}$ concentration $\left(K_{100 \%}\right)$ was calculated from the second-order derivative of each regression equation. The maximum yield [95\% maximum yield $\left.\left(Y_{95 \%}\right)\right]$ and its corresponding leaf $\mathrm{K}$ concentration $\left(K_{95 \%}\right)$ were then calculated by inserting $Y_{95 \%}$ into the regression equation obtained and solving for $K_{95 \%}$. The $K_{95 \%}$ is often used as the reference point to diagnose plant $\mathrm{K}$ status (sufficient vs. deficient) and is referred to as the critical leaf $\mathrm{K}$ value for optimal crop production (Marschner, 1995).

Statistical analysis. Data were analyzed using the Superanova statistical software (Version 1.11, Abacus Concept, San Francisco, Calif.). The means were separated by Fisher's protected least significance difference (LSD) test at $P \leq 0.05$. Regression analysis was performed for nut yield vs. leaf $\mathrm{K}$ concentration.

\section{Results}

Effects on soil $\mathrm{NH}_{4}^{+}$-extractable $\mathrm{K}$. Initially, the soil $\mathrm{NH}_{4}^{+}$-extractable $\mathrm{K}$ was low, suggesting the need to apply K (Fig. 1). Soil $\mathrm{NH}_{4}{ }^{+}-$ extractable $\mathrm{K}$ increased significantly as a result of $\mathrm{K}$ fertilizations at the annual rate of 110 to $330 \mathrm{~kg} \cdot \mathrm{ha}^{-1}$ (Fig. 1). For example, after 3 years of annual application of $220 \mathrm{~kg} \cdot \mathrm{ha}^{-1}$, the $\mathrm{NH}_{4}{ }^{+}$ extractable $\mathrm{K}$ in the soil $0-15 \mathrm{~cm}$ profile was five times that in the control plots. In contrast, soil $\mathrm{K}$ declined sharply in the control plots not receiving $\mathrm{K}$ fertilizers, resulting in further depletion of soil $\mathrm{K}$. The magnitude of soil $\mathrm{K}$ increase was much more profound in the surface $30 \mathrm{~cm}$ than in the deeper layers.

In K-treated plots, $\mathrm{K}$ applied to the soil surface moved downward in the soil profile, resulting in significantly higher soil $\mathrm{K}$ content than in the control plots. As $\mathrm{K}$ input increased, more K moved to deeper soil layers. The higher concentration of $\mathrm{K}$ in surface soil suggests that the majority of applied $\mathrm{K}$ was held near the surface and that its downward movement was slow.

Effects on leaf $K$ concentration. The trees exhibited highly dynamic seasonal leaf $\mathrm{K}$ fluctuations (Fig. 2). During spring flush from April to May, leaf K concentration fell below $10 \mathrm{~g} \cdot \mathrm{kg}^{-1}$. As fruit development proceeded, leaf $\mathrm{K}$ concentration increased dramatically, with the most significant increase occurring from July to September, the peak nut-fill period

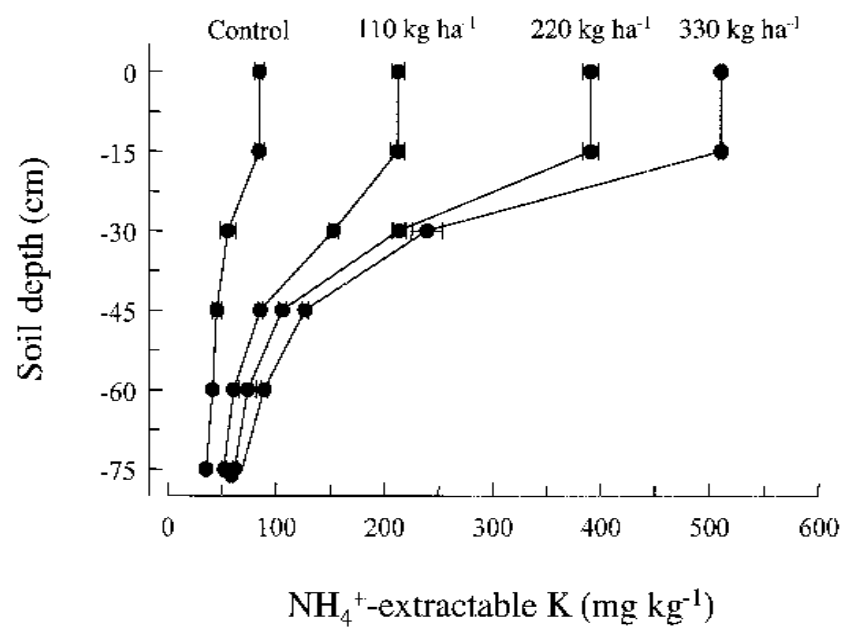

Fig. 1. K distribution in soil profile in Madera pistachio orchard after 3 years of $\mathrm{K}$ fertilization at various annual rates. Each value is the average of five replicates \pm SE. 
when $\mathrm{K}$ demand and accumulation in maturing nuts are maximal. Leaf $\mathrm{K}$ concentration declined rapidly after harvest in September.

Fertilization with $\mathrm{K}$ increased leaf $\mathrm{K}$ concentration (Fig. 2). Leaf $\mathrm{K}$ concentration in July averaged $11 \mathrm{~g} \cdot \mathrm{kg}^{-1}$ over the 3 -year period in the control trees vs. 15 to $19 \mathrm{~g} \cdot \mathrm{kg}^{-1}$ in the trees receiving 110 to $330 \mathrm{~kg} \cdot \mathrm{ha}^{-1} \mathrm{~K}$ annually. Leaf $\mathrm{K}$ concentration was significantly higher in trees receiving $330 \mathrm{~kg} \cdot \mathrm{ha}^{-1}$ than in those receiving 110 or $220 \mathrm{~kg} \cdot \mathrm{ha}^{-1}$ (Fig. 3). As annual $\mathrm{K}$ application rate increased from 110 to $330 \mathrm{~kg} \cdot \mathrm{ha}^{-1}$, leaf $\mathrm{Ca}^{2+}$ fell from 20.5 to 15.6 $\mathrm{g} \cdot \mathrm{kg}^{-1}$ and leaf $\mathrm{Mg}^{2+}$ from 4.2 to $3.3 \mathrm{~g} \cdot \mathrm{kg}^{-1}$ (Fig. 3). Leaf K concentrations did not differ among the three $\mathrm{K}$ sources $\left(\mathrm{K}_{2} \mathrm{SO}_{4}, \mathrm{KCl}\right.$, and $\left.\mathrm{KNO}_{3}\right)$ (data not shown).

Effects on nut yield. The average nut yield was $2166 \mathrm{~kg} \cdot \mathrm{ha}^{-1}$ in the control plots not receiving $\mathrm{K}$ fertilizers (Fig. 4). In contrast, when $\mathrm{K}$ was applied annually at 110 to $220 \mathrm{~kg} \cdot \mathrm{ha}^{-1}$, the trees yielded 3142 to $3560 \mathrm{~kg} \cdot \mathrm{ha}^{-1}$. How- ever, a further increase to $330 \mathrm{~kg} \cdot \mathrm{ha}^{-1}$ reduced yield to $3138 \mathrm{~kg} \cdot \mathrm{ha}^{-1}$. There was no significant difference in the average nut yield between the three K sources used, when applied at the same rate of $\mathrm{K}$ (data not shown).

Effects on nut quality. A high percentage of split nuts and a high 100-nut weight are desirable, as are low percentages of blank and stained nuts. Application of $\mathrm{K}$ increased percentages of split nuts and 100-nut weight, while reducing percentages of blank and stained nuts (Fig. 5), suggesting improved nut quality as a result of $\mathrm{K}$ fertilization. Neither $\mathrm{K}$ application rate $\left(110,220\right.$, and $\left.330 \mathrm{~kg} \cdot \mathrm{ha}^{-1}\right)$ nor K source affected these quality parameters (data not shown).

Note that the results presented are averages for 3 years, and that yield-to-yield fluctuations in responses to $\mathrm{K}$ in terms of leaf $\mathrm{K}$ concentration and nut yield and quality, were observed. Responses to K tended to increase with time, but the year-to-year difference was nonsig-

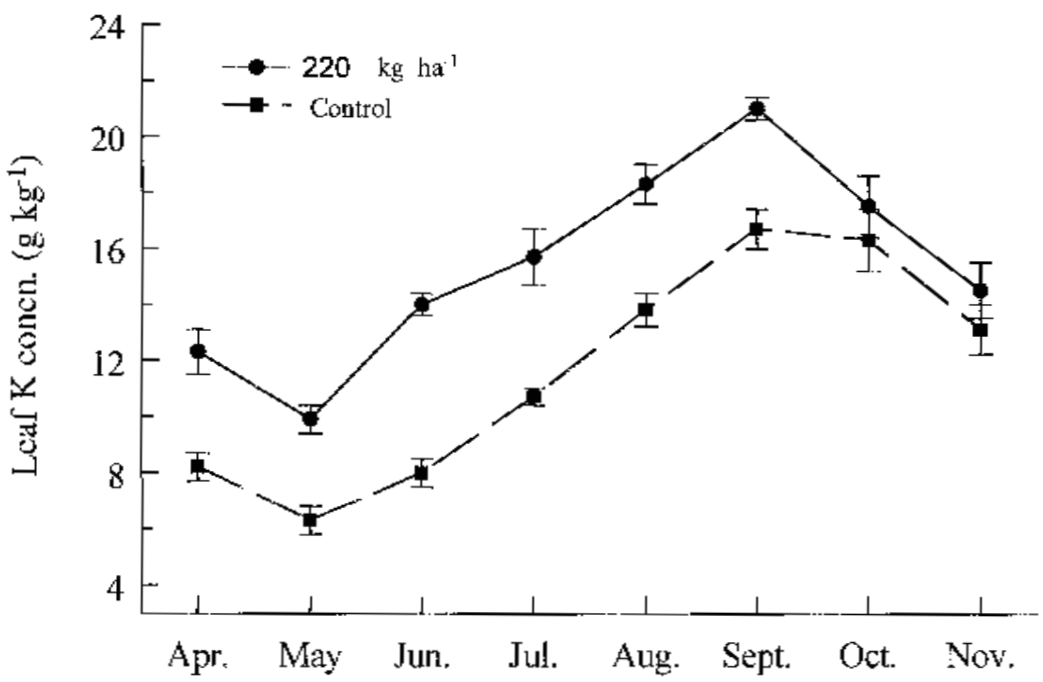

Fig. 2. Effect of K application on seasonal variation in leaf $\mathrm{K}$ concentration in pistachio in 1998. K was applied as $\mathrm{K}_{2} \mathrm{SO}_{4}$. Each value is the average of five replicates $\pm \mathrm{SE}$.

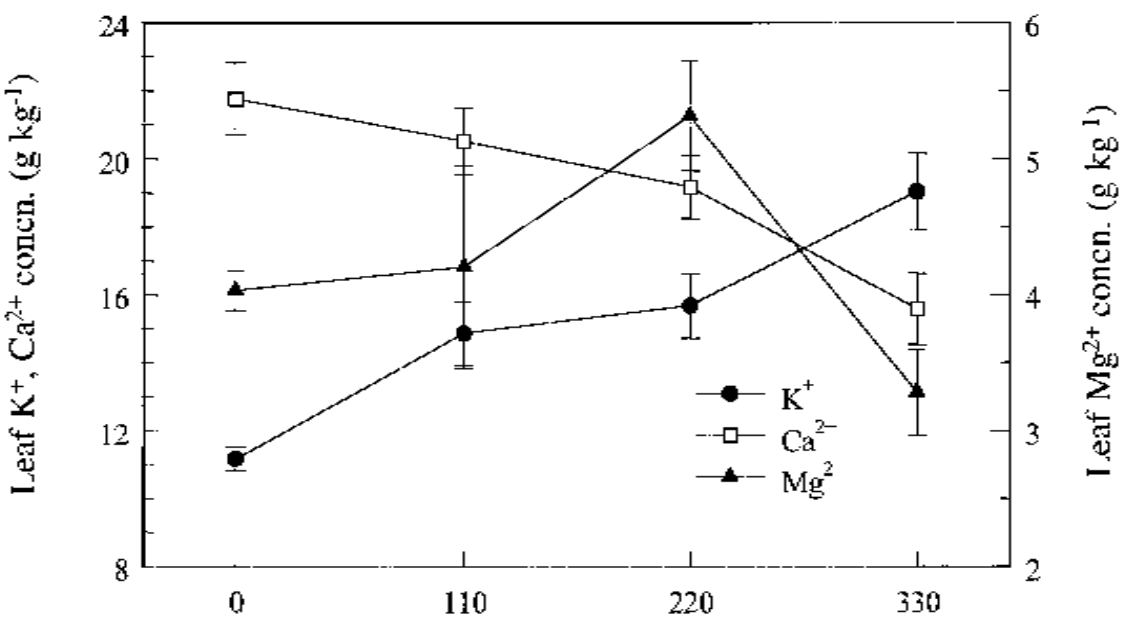

Annual $\mathrm{K}$ application rate $\left(\mathrm{kg} \mathrm{ha}^{-1}\right)$

Fig. 3. Changes in leaf $\mathrm{K}^{+}, \mathrm{Ca}^{2+}$, and $\mathrm{Mg}^{2+}$ concentrations in pistachio leaves sampled in July 1998 in response to $\mathrm{K}$ applied as $\mathrm{K}_{2} \mathrm{SO}_{4}$ at various rates. Each value is the average of five replicates $\pm \mathrm{SE}$. nificant (data not shown).

Effects on leaf chloride concentration. Leaf $\mathrm{Cl}^{-}$concentration did not differ $(P \leq 0.05)$ among $\mathrm{K}$ sources (data not shown), with all values falling within the optimal $\mathrm{Cl}^{-}$range (1 to $3 \mathrm{~g} \cdot \mathrm{kg}^{-1} \mathrm{Cl}$ ) suggested by Brown (1995).

$K$ diagnostic criteria for maximum pistachio production. Average nut yield was positively correlated with average leaf K concentration during nut fill $(P \leq 0.05)$ (Fig. 6). The $Y_{100 \%}$ was $3615 \mathrm{~kg} \cdot \mathrm{ha}^{-1}$, and the corresponding $K_{100 \%}$ during nut fill $19.6 \mathrm{~g} \cdot \mathrm{kg}^{-1} \mathrm{~K}^{+}$. The $Y_{95 \%}$ was $3434 \mathrm{~kg} \mathrm{ha}^{-1}$, the corresponding $K_{95 \%} 16.9$ $\mathrm{g} \cdot \mathrm{kg}^{-1} \mathrm{~K}^{+}$.

\section{Discussion}

Pistachio trees exhibit highly dynamic seasonal K fluctuations, as do many other perennial tree crops (Marschner, 1995). Our results show that leaf $\mathrm{K}$ was low during spring flush, increased dramatically during fruit development, and declined rapidly after harvest. Similar seasonal leaf $\mathrm{K}$ changes were observed in all 3 years (data not shown).

Low leaf $\mathrm{K}$ concentration during spring flush may be partially attributed to a dilution effect resulting from rapid leaf expansion and increase in leaf mass (Marini and Marini, 1983; Orland, 1963), rather than an actual decrease in leaf $\mathrm{K}$ content (Rogers et al., 1953). Conversely, increases in leaf K concentration during fruit development indicate that: 1) Kaccumulates as the season progresses; and 2) the accumulation rate exceeds that of dry matter in leaves (Picchioni et al., 1997). Rapid increase in leaf $\mathrm{K}$ concentration during fruit development in pistachio is atypical of perennial fruit crops (Sparks, 1977) and is considered to be associated with greater apparent $\mathrm{K}$ uptake, which is driven by sink demand for K in the fruit (Brown et al., 1995; Picchioni et al., 1997). The high K demand and uptake during nut fill suggest that a sufficient supply of $\mathrm{K}$ to the tree during this period is critical for satisfactory nut filling. The rapid decline in leaf $\mathrm{K}$ concentration after harvest suggests that leaf $\mathrm{K}$ is translocated to other tree parts, e.g., trunk, to build the tree $\mathrm{K}$ storage pool that supplies significant amounts of $\mathrm{K}$ to the spring flush in the following year (Rosecrance et al., 1996, 1998).

Our results show that an annual $\mathrm{K}$ input exceeding $220 \mathrm{~kg} \cdot \mathrm{ha}^{-1} \mathrm{~K}$ tended to reduce pistachio nut yield. Although the specific causes of this reduction are unclear, they may be associated with significantly reduced leaf $\mathrm{Ca}^{2+}$ and $\mathrm{Mg}^{2+}$ concentrations, both of which were below the optimal values suggested by Brown (1995). Reduced leaf $\mathrm{Ca}^{2+}$ and $\mathrm{Mg}^{2+}$ concentrations as a result of high $\mathrm{K}$ input have also been reported in citrus (Koo, 1985) and many other deciduous tree crops (Cummings, 1985). In Greece, Procopiou and Wallace (1978) observed $\mathrm{Mg}$-induced $\mathrm{K}$ deficiency in pistachio, and inhibition of the uptake of $\mathrm{Ca}^{2+}$ and $\mathrm{Mg}^{2+}$ by high soil $\mathrm{K}^{+}$is well documented (Dibb and Thompson, 1985; Marschner, 1995). Mengel and Kirkby (1982) suggested that K-Ca and K$\mathrm{Mg}$ antagonisms could be explained in terms of competition for carrier binding sites on root 


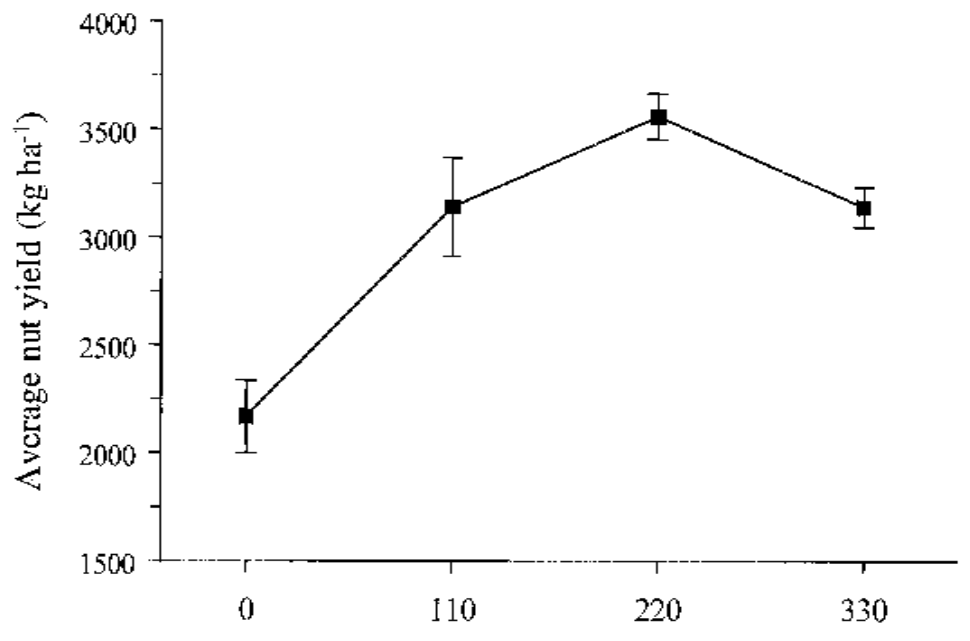

Annual $\mathrm{K}$ application rate ( $\left.\mathrm{kg} \mathrm{ha}^{-1}\right)$

Fig. 4. Yield of in-shell pistacio nuts (average of 3 years) as affected by $\mathrm{K}$ applied as $\mathrm{K}_{2} \mathrm{SO}_{4}$. Each value is the average of five replicates $\pm \mathrm{SE}$

cell membranes or ionic balance effects within the plant, which may differ among species (Dibb and Thompson, 1985).

Application of K obviously improves nut quality in pistachio, with increased percentages of split nuts and 100-nut weight, and reduced percentages of blank and stained nuts. Increased percentages of split nuts and greater nut weight are indicative of enhanced nut filling, probably because of enhanced photosynthesis (Pflüger and Cassier, 1977) and photoassimilate transport (Marschner, 1995) to the developing nuts in K-treated pistachio trees. Stained nuts are usually caused by fungi, i.e., Botroyspheria $s p$. or Alternaria $s p$., as pistachio trees are highly susceptible to fungal infections in microsprinkler-irrigated orchards with high humidity inside the canopy (Michailides et al., 1995). Reduced nut staining in the $\mathrm{K}$-treated trees indicates that $\mathrm{K}$ application may decrease susceptibility to diseases, possibly by enhancing synthesis of high-molecular-weight compounds, e.g. proteins, starch, and cellulose (Marschner, 1995). Note that the experiment was conducted on a soil with light texture, where tree responses to $\mathrm{K}$ fertilization would generally be more significant than on a soil with heavier texture.

One concern over the use of $\mathrm{KCl}$ as the $\mathrm{K}$ source is the possible $\mathrm{Cl}$ toxicity resulting from $\mathrm{Cl}^{-}$accumulation in the plant tissue. Our results show that $\mathrm{KCl}$ fertilization for 3 years did not result in a significant increase in leaf $\mathrm{Cl}^{-}$concentration, suggesting that $\mathrm{Cl}^{-}$uptake and accumulation in the pistachio tree may be minimal when $\mathrm{KCl}$ is applied as the $\mathrm{K}$ source. As a species originating in semiarid and arid regions characterized by high salinity, pistachio is considered to be a salt-tolerant species (Sepaskhah and Maftoun, 1981). Pistachio trees may possess certain salt-tolerating mechanisms that exclude $\mathrm{Cl}^{-}$uptake from the soil, preventing $\mathrm{Cl}^{-}$accumulation in the tree. Alternatively, a mechanism in the pistachio tree may limit translocation of the absorbed $\mathrm{Cl}^{-}$ from the root to the aboveground parts of the tree. However, concentrations of $\mathrm{Cl}$ in the root and the trunk were not determined in this study, and the data presented herein are insufficient to suggest whether these mechanisms exist in pistachio.

Our results show that the critical leaf $\mathrm{K}$ value for optimal pistachio production was 16 $\mathrm{g} \cdot \mathrm{kg}^{-1} \mathrm{~K}^{+}$or higher, a value much higher than the values of 7 to $10 \mathrm{~g} \cdot \mathrm{kg}^{-1} \mathrm{~K}^{+}$previously suggested (Ashworth et al., 1985; Uriu and Crane, 1977). Previous estimates were based on the expression of visual deficiency symptoms in the leaf, whereas the optimal leaf $\mathrm{K}$ concentration of $16 \mathrm{~g} \cdot \mathrm{kg}^{-1}$ or higher at nut fill determined in this experiment is based upon 3 years of nut yields. Under the experimental condition, these levels of leaf $\mathrm{K}$ were maintained by annual application of 110 to 220 $\mathrm{kg} \cdot \mathrm{ha}^{-1} \mathrm{~K}$. This matches closely the estimated
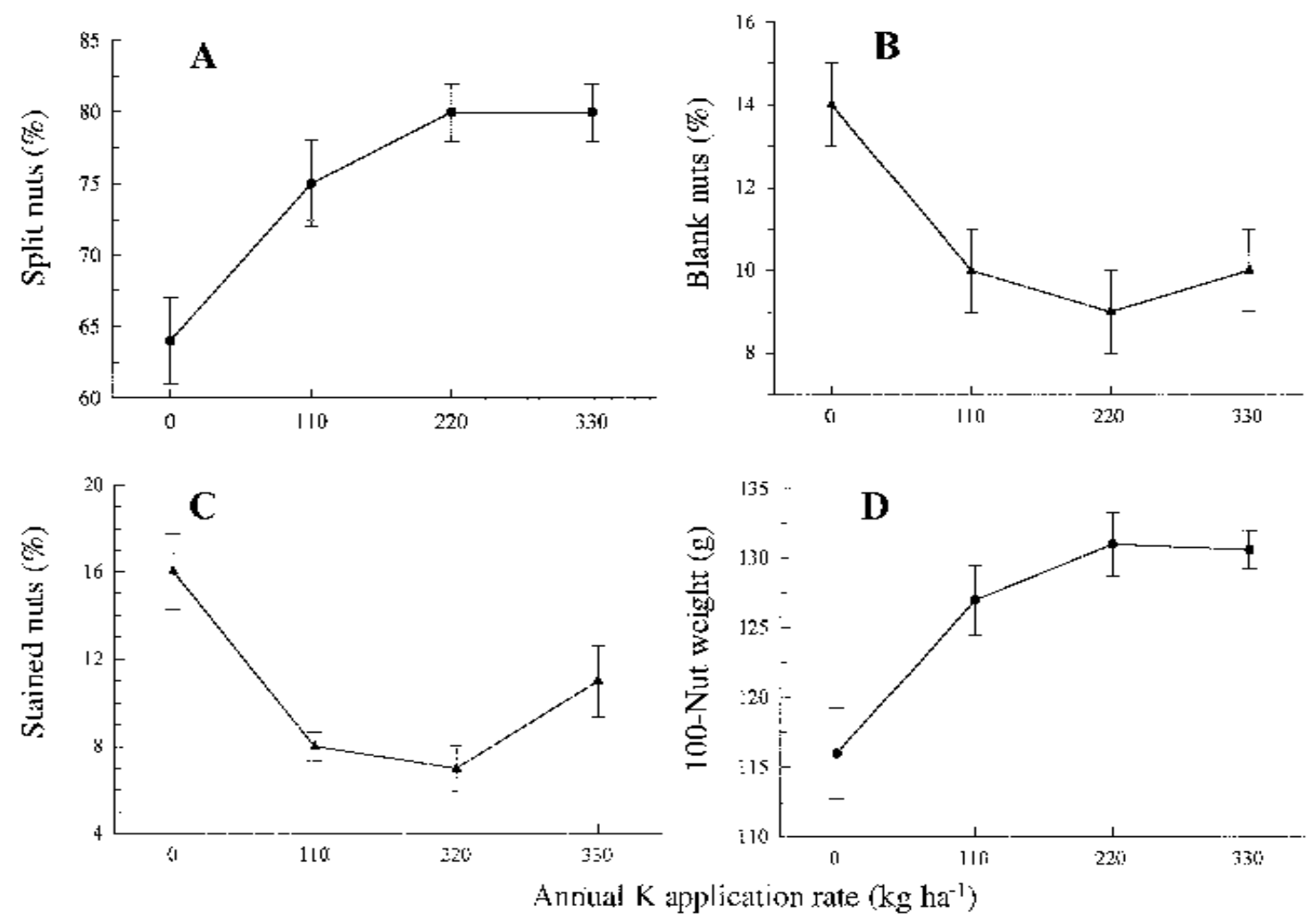

Fig. 5. Effects of K application on (A) split nuts, (B) blank nuts, (C) stained nuts, and (D) 100 nut weight. 


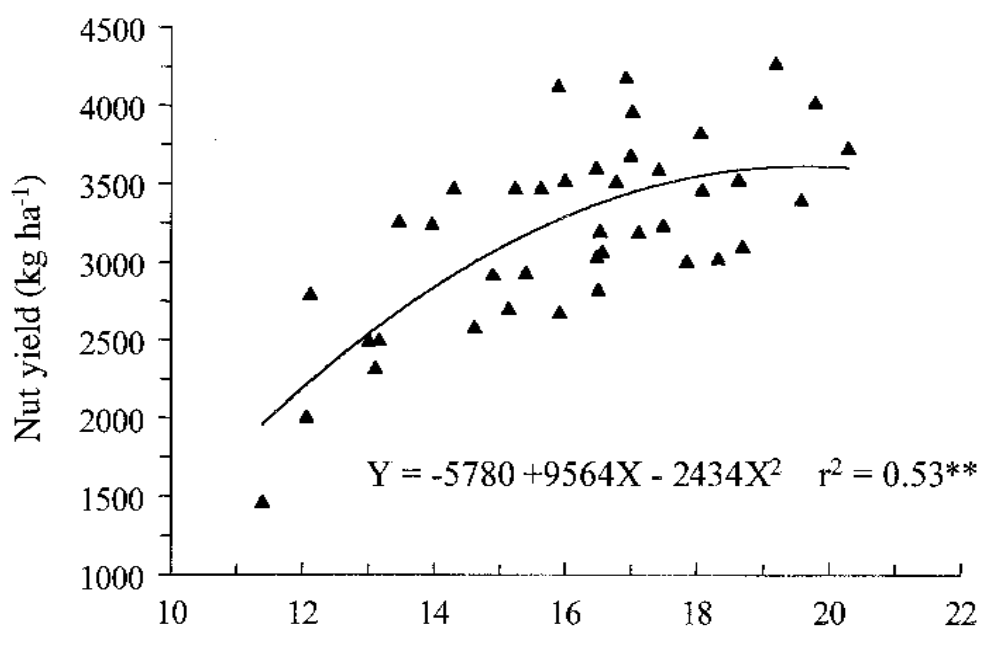

Leaf $\mathrm{K}$ concn. $\left(\mathrm{g} \mathrm{kg}^{-1}\right)$

Fig. 6. The relationship between nut yield of pistacio and leaf $\mathrm{K}$ concentration during nut fill.

annual crop $\mathrm{K}$ removal of $227 \mathrm{~kg} \cdot \mathrm{ha}^{-1} \mathrm{~K}$ by heavily-cropping trees determined by Rosecrance et al. (1996).

Based on regression analysis (Fig. 6), we recommend that, for optimal pistachio production in California, $\mathrm{K}$ fertilizers be applied annually at the rate of 110 to $220 \mathrm{~kg} \cdot \mathrm{ha}^{-1}$ to maintain a leaf $\mathrm{K}$ concentration of $16 \mathrm{~g} \cdot \mathrm{kg}^{-1}$ or higher at nut fill, using either $\mathrm{K}_{2} \mathrm{SO}_{4}$ or $\mathrm{KCl}$ or $\mathrm{KNO}_{3}$.

\section{Literature Cited}

Ashworth, L.J., S.A. Gaona, and E. Surber. 1985. Nutritional diseases of pistachio trees: Potassium and phosphorus deficiencies and chloride and boron toxicities. Phytopathology 75:1084-1091.

Brown, P.H. 1995. Diagnosing and correcting nutrient deficiencies, p. 95-100. In: L. Ferguson (ed.). Pistachio production. Univ. Calif., Davis.

Brown, P.H., S.A. Weinbaum, and G.A. Picchioni. 1995. Alternate bearing influences annual nutrient consumption and the total nutrient content of mature pistachio trees. Trees 9:158-164.

Cassman, K.G., T.A. Kirby, B.A. Roberts, D.C. Bryant, and S.M. Brouder. 1989. Differential response of two cotton cultivars to fertilizer and soil potassium. Agron. J. 81:870-876.

Chung, J.B. and R.J. Zasoski. 1993. Effects of high ammonium levels on nitrification, soil acidification, and exchangeable cation dynamics. Commun. Soil Sci. Plant Anal. 24:2123-2135.

Cummings, G.A. 1985. Potassium nutrition of deciduous and small fruits, p. 1087-1104. In: R.D. Munson (ed.). Potassium in agriculture. Amer. Soc. Agron.-Crop Sci. Soc. Amer.-Soil Sci. Soc. Amer., Madison, Wis.

Dibb, D.W. and W.R. Thompson. 1985. Interaction of potassium with other nutrients, p. 515-534. In: R.D. Munson (ed.). Potassium in agriculture. Amer. Soc. Agron.-Crop Sci. Soc. Amer.-Soil Sci. Soc. Amer., Madison, Wis.

Ferguson, L., A. Kader, and J. Thompson. 1995. Harvesting, transporting, processing and grading, p. 110-114. In: L. Ferguson (ed.). Pistachio production. Univ. Calif., Davis.

Gee, G.W. and J.W. Bauder. 1986. Particle-size analysis, p. 383-412. In: A. Klute (ed.). Meth- ods of soil analysis. Part 1. Monogr. No. 9, Amer. Soc. Agron., Madison, Wis.

Hendershot, W.H., H. Lalande, and M. Duquette. 1993. Ion exchange and exchangeable cations, p. 167-176. In: M.R. Carter (ed.). Soil sampling and methods of analysis. Lewis Publishers, Boca Raton, Fla.

Johnson, R.S. and S.A. Weinbaum. 1987. Variation in tree size, yield, cropping efficiency, and alternate bearing among 'Kerman' pistachio trees. J. Amer. Soc. Hort. Sci. 112:942-945.

Koo, R.C. 1985. Potassium nutrition of citrus, p. 1077-1086. In: R.D. Munson (ed.). Potassium in agriculture. Amer. Soc. Agron.-Crop Sci. Soc. Amer--Soil Sci. Soc. Amer., Madison, Wis.

Marini, R.P. and M.C. Marini. 1983. Seasonal changes in specific leaf weight, net photosynthesis, and chlorophyll content of peach leaves as affected by light penetration and canopy position in Prunus persica. J. Amer. Soc. Hort. Sci. 108:609-613.

Marschner, H. 1995. Mineral nutrition of higher plants. $2^{\text {nd }}$ ed. Academic, San Diego.

Mengel, K. and E.A. Kirkby. 1982. Principles of plant nutrition. Intl. Potash Inst., Berne, Switzerland.

Michailides, T.J., D.P. Morgan, and M.A. Doster. 1995. Foliar and fruit fungal diseases, p. 148160. In: L. Ferguson (ed.). Pistachio production. Univ. Calif., Davis.

Nelson, D.W. and L.E. Sommers. 1982. Total carbon, organic carbon, and organic matter, p. 539579. In: A.L Page, R.H. Miller, and D.R. Keeney (eds.). Methods of soil analysis: Chemical and microbiological properties. $2^{\text {nd }}$ ed. Agron. Monogr. No. 9 Part 2, Amer. Soc. Agron., Madison, Wis.

Olk, D.C., K.G. Cassman, and R.M. Carlson. 1995. Kinetics of potassium fixation in vermiculitic soils under different moisture regimes. Soil Sci. Soc. Amer. J. 59:423-429.

Orland, K. 1963. Changes in the content of dry matter and major nutrient elements of apple foliage during senescence and abscission. Physiol. Plant. 16:682-694.

Pfluger, R. and A. Cassier, 1977. Influence of monovalent cations on photosynthetic $\mathrm{CO}_{2}$ fixa- tion. Proc. $13^{\text {th }}$ Colloq. Intl. Potash Inst., Berne, Switzerland.

Picchioni, G.A., P.H. Brown, S.A. Weinbaum, and T.T. Muraoka. 1997. Macronutrient allocation to leaves and fruit of mature, alternate-bearing pistachio trees: Magnitude and seasonal patterns at the whole-canopy level. J. Amer. Soc. Hort. Sci. 122:267-274.

Procopiou, J. and A. Wallace. 1978. A nutritional disorder in pistachio from near Athens, Greece. Commun. Soil Sci. Plant Anal. 9:931-934.

Righetti, T.L., K.L. Wilder, and G.A. Cummings. 1990. Plant analysis as an aid in fertilizing orchards, p. 563-591. In: R.L. Westerman (ed.). Soil testing and plant analysis. 3rd ed. Soil Sci. Soc. Amer., Madison, Wis.

Rogers, B.L., L.P. Batjer, and A.H. Thompson. 1953. Seasonal trend of several nutrients in Delicious apple leaves expressed on a percent and unit area basis. Proc. Amer. Soc. Hort. Sci. $61: 1-5$.

Rosecrance, R.C. 1996. The effects of alternate bearing on nutrient uptake, storage, and root growth in mature pistachio (Pistacia vera $\mathrm{L}$.) trees. PhD Diss., Pomology Dept., Univ. Calif., Davis.

Rosecrance, R.C., S.A. Weinbaum and P.H. Brown. 1996. Assessment of nitrogen, phosphorus, and potassium uptake capacity and root growth in mature alternate bearing pistachio (Pistacia vera). Tree Physiol. 16:949-956.

Rosecrance, R.C., S.A. Weinbaum, and P.H. Brown. 1998. Alternate bearing affects nitrogen, phosphorus, potassium and starch storage pools in mature pistachio trees. Ann. Bot. 82:463-470.

Sepaskhah, A.R. and M. Maftoun. 1981. Growth and chemical composition of pistachio cultivars as influenced by irrigation regimes and salinity levels of irrigation water. II. Chemical composition. J. Hort. Sci. 57:469-476.

Sparks, D. 1977. Effects of fruiting on scorch, premature defoliation and nutrient status of Chickasaw pecan leaves. J. Amer. Soc. Hort. Sci. 102:669-673.

Uriu, K. and J.C. Crane. 1977. Mineral element changes in pistachio. J. Amer. Soc. Hort. Sci. 102:155-158

Weinbaum, S.A., R.S. Johnson, and T.M. DeJong. 1992. Causes and consequences of overfertilization in orchards. HortTechnology 2:112-121.

Weinbaum, S.A., G.A. Picchioni, T.T. Muraoka, P.H. Brown, and L. Ferguson. 1994. Nitrogen usage, accumulation of carbon and nitrogen reserves, and the capacity for labeled fertilizer nitrogen and boron uptake varies during the alternate-bearing cycle in pistachio. J. Amer. Soc. Hort. Sci. 119:24-31.

Zeng, Q. 1999. Soil potassium mobility and uptake under differential soil moisture regimes and potassium nutrition of mature pistachio trees. PhD Diss, Pomology Dept., Univ. Calif., Davis.

Zeng, Q., P.H. Brown, T. Fairweather, and B.A. Holtz. 1997. Potassium nutrition of pistachio: Development of diagnostic procedures and fertilizer recommendations (First year report). California Pistachio Ind. Annu. Rpt. 1996-97 Crop year, Calif. Pistachio Comm.

Zeng, Q., P.H. Brown, C. Hornung, and B.A. Holtz. 1998. Effects of potassium application on soil potassium availability, leaf potassium status, nut yield and quality in mature pistachio (Pistacia vera L.) trees. California Pistachio Ind. Annu. Rpt. 1997-98 Crop year, Calif. Pistachio Comm. 